GRANDON GILL

\title{
LEE-EN CHUNG: SHOULD I HAVE A WEBSITE? ${ }^{1}$
}

\author{
Of course I've considered having a website. I'm just not sure how it would benefit me...
}

Lee-En Chung, the owner of Ivy Ventures, Inc., smiled mischievously as she made this comment. The conventional wisdom was that every business needed a website. Her business - a one person construction consulting firm - had done very well without the web. Instead, she had always focused on building relationships. By doing so she had managed to succeed in a heavily male-dominated profession, developing her own unique style in the process. She laughed as she told the story about the pink plastic skin that covered her laptop keyboard and coordinated with her cell phone. On the practical side, it kept out the dust of the construction sites that she visited nearly every day. But the color served an equally important role. None of the workers she dealt with would consider even touching — much less walking off withanything that pink! In other words, form and function complemented each other perfectly.

Beyond her personal style, Chung's business had been built upon her remarkable adaptability. When new construction had almost completely dried up as a result of the 2007-2008 real estate and financial meltdown, she had developed a new specialty in an area that still had some life: engineering consulting on the construction of sports venues. Three years before, she admitted, "I knew nothing about baseball." Now she was an expert and had recently acted as the liaison among the county, the team owners, and the construction crews during the renovation of the spring training facility for the Baltimore Orioles. In a month, she would also be launching a blog on sports venues for Yahoo! Sports.

Part of being adaptable, however, was recognizing that things sometimes changed. The year 2011 had been toughest year for construction projects in living memory. The year 2012 was not shaping up to be much better. If a website could be useful in helping her to weather the storm, she certainly would not object to having one. But before she made the investment in building and maintaining such a site - with time being the main issue, more than money-she need to see a strong business case. Would such a site attract new business, or simply be a matter of ego? Could a site be constructed that reflected her personal style, or would it be generic, making her seem like one of the crowd? What type of marketing activities would be needed to complement the website? Would the site consist mainly of static pages, or would there be content that could engage and inform the user? If there were lots of activity on the site, how much of her own time would be required to keep it fresh? How could she tell if the site was effective? With the right answers to these questions, perhaps a website might make sense after all.

\footnotetext{
${ }^{1}$ Copyright $($ 2012, Informing Science Institute. This case was prepared for the purpose of class discussion, and not to illustrate the effective or ineffective handling of an administrative situation. Names and some information have been disguised. Permission is granted to copy and distribute this case for non-commercial purposes, in both printed and electronic formats. This material is based upon work supported by the National Science Foundation under Grant No. 1043919.
} 


\section{Commercial Construction Consulting}

Managing any construction project is complex. Project schedules need to be arranged so that different activities occur in a sensible order. Underground plumbing connections, for example, may need to be installed before the foundation is poured. Electrical wiring must be sequenced between the framing of a structure and the installation of drywall. Required city and county permits must be acquired and inspections performed at specific points in the process. Missing a required inspection, for example, can mean that work done subsequently must be ripped out and then done over once the inspector has been satisfied.

Beyond the issues associated with construction in general, commercial projects have their own particular set of challenges. A typical commercial project normally involves many parties: developers, architects, construction companies, owners, tenants, state and local governments, environmental agencies, and banks, to name just some. The interests of these parties are not necessarily aligned. Unlike residential developments, where many units are developed according to similar or identical plans, each commercial construction project tends to have unique aspects. In addition, whereas residential projects tend to be valued based upon the selling price of comparable units, commercial projects tend to be valued according to the economic factors driving the particular project - the rent it is likely to command, the vacancy it is likely to experience, and the revenues that the businesses that occupy the property are likely to generate.

\section{Role of the Construction Consultant}

Within the commercial construction process, the construction consultant often plays a vital role. Typically hired by one or more of the parties to the project, the consultant monitors the project, both to assess its progress and to ensure that necessary activities are conducted in the proper order and that key details, such as pulling required permits and mandatory inspections, are not missed.

The consultant can play a particularly pivotal role in project financing and is, therefore, often hired by the bank or lending institution associated with the project. Because commercial projects tend to be large, they are generally financed with loans. Such loans, however, are not normally made as a single outlay. Instead, the loan contract specifies that funds will be released to the contractor as the project progresses, according to certain milestones. This can be critical in ensuring a project gets completed according to budget because, with immediate access to all project funds, many contractors would fail to budget adequately and then run out of money before the project was complete. The obvious drawback of the progress payment arrangement is that many contractors often cannot afford to pay their employees and subcontractors out of pocket while awaiting the release of funds. Thus, one important role that a consultant can play — serving the needs of both the financial institution and the contractor-is to identify milestone completions that then permit the contractor to access the next round of funds. That role also gives the consultant considerable leverage in ensuring that all contracted activities are being conducted correctly.

Another class of activities that a construction consultant frequently performs is miscellaneous quality checks. This type of check can occur at virtually any stage of the design and construction process. At the beginning of the process, a properly qualified consultant might double check the architectural drawings to ensure they meet the owner's and contractor's needs. At the other end of the process, the consultant might do a final quality inspection of the finished product. Chung, for example, had recently finished inspecting 3,000 seats in the newly renovated Ed Smith Stadium in Sarasota, Florida, used by the Baltimore Orioles for spring training. The seats had been taken from the legendary Camden Yards stadium in Baltimore and refurbished. Chung's job was to visually inspect each one, do a mechanical inspection of each oneensuring the seats flipped up and down properly, that the seat number was affixed correctly, and that the cup holders were secure. She even checked that the anchor bolts holding each seat down were cut and trimmed in such a way that they would not catch on articles of clothing worn by fans. 


\section{Construction Consultants and Licensing}

The term "consultant" is broad in nature and generally does not mandate any particular qualification. As is the case for many occupations, however, licenses CAN be obtained that enhance the consultant's credibility. Chung had two of these, being licensed as a general contractor and as a professional engineer. These qualifications made her relatively unique. In fact, she had been told that she was the first woman in Florida to earn both licenses.

The general contractor's license allowed the individual to pull permits and perform a variety of tasks, as described by the Florida Statutes in Exhibit 1. In order to acquire a contractor's license, the individual needed to have a combination of work experience, schooling and also needed to pass a certification exam.

In order to describe oneself as an "engineer", a different certification was needed. According to the 2011 Florida Statutes (Section 471.005.7) engineering was defined as follows:

"Engineering" includes the term "professional engineering" and means any service or creative work, the adequate performance of which requires engineering education, training, and experience in the course application of special knowledge of the mathematical, physical, and engineering sciences to such services or creative work as consultation, investigation, evaluation, planning, and design of engineering works and systems, planning the use of land and water, teaching of the principles and methods of engineering design, engineering surveys, and the inspection of construction for the purpose of determining in general if the work is proceeding in compliance with drawings and specifications, any of which embraces such services or work, either public or private, in connection with any utilities, structures, buildings, machines, equipment, processes, work systems, projects, and industrial or consumer products or equipment of a mechanical, electrical, hydraulic, pneumatic, or thermal nature, insofar as they involve safeguarding life, health, or property; and includes such other professional services as may be necessary to the planning, progress, and completion of any engineering services. A person who practices any branch of engineering; who, by verbal claim, sign, advertisement, letterhead, or card, or in any other way, represents himself or herself to be an engineer or, through the use of some other title, implies that he or she is an engineer or that he or she is licensed under this chapter; or who holds himself or herself out as able to perform, or does perform, any engineering service or work or any other service designated by the practitioner which is recognized as engineering shall be construed to practice or offer to practice engineering within the meaning and intent of this chapter.

The requirements for a professional engineer's license were substantial — in addition to the certifying exam, engineers normally were required to have a 4-year engineering degree in an appropriate field, such as civil engineering, from an accredited institution as well as a minimum of four years of work experience in a professional engineering capacity.

Some types of construction, such as plumbing and electrical systems, required other certifications than those of the general contractor or engineer. In addition, certifications were available for specialty construction areas. For example, Leadership in Energy and Environmental Design Accredited Professional (LEED AP) certification meant that the individual had demonstrated extensive knowledge and skill in the design and construction of energy-efficient (a.k.a., green) buildings. Each of these certifications has its own licensing boards, exams and associated requirements.

\section{Lee-En Chung}

Born in New York City to immigrant parents from Taiwan, Lee-En Chung grew up in Florida. In the mid1980s, she returned to New York where she attended Columbia University, the prestigious Ivy League 
school located in New York City. In the late 1980s, she received her B.S. in Civil Engineering. Her first job was in the facilities department of NBC, where she was primarily engaged in renovating offices and newsrooms at prestigious locations, such as the well-known "30 Rock." The job offered a great deal of day-to-day variety - one day she might be working on News 4 New York, Today Show, or NBC Sports, the next she might be helping out with the design of a new dressing room for David Letterman (one of her favorite projects).

\section{Early Career}

After leaving NBC, Chung joined The George Hyman Construction Company (which is now known as Clark Company) in the Washington, D.C. area. There she did estimates on new projects valued around $\$ 100$ million. She also worked on-site for major projects, such as the AARP Headquarters building, where she coordinated the installation of mechanical and electrical systems for the 10-story building's more than 16 elevators. In the period from 1990 to 1992 she was assigned to work on-site during the construction of the VA Medical Center in Palm Beach Gardens, Florida. At that time, she voraciously studied for months for the Florida general contractor's exam. When she took it - in the Miami Convention Center with over 1,000 males and a mere five or so females - she actually passed the exam (all three parts) the first time. There were two factors that particularly influenced the decision to take the exam. The first was the relatively slow career progression that she could expect at a large construction firm, particularly as a woman - a novelty at the time. The second was the experiences of her mother, an architect who had passed away while she was younger, and her father, an engineer, both of whom had been very entrepreneurial.

After earning her license as a state-certified general contractor in 1991, quitting her job in early 1992, and then heading to Ecuador to figure out what to do with her life. Upon returning, she founded Ivy Ventures in March of 1992. Getting started in the business was a major challenge, however. Florida was in one of its periodic residential real estate slumps in the early 1990s so new construction activity was limited. Chung took on a series of very small projects - anything that would pay the bills.

Her first real break came in 1993. She had joined the local Home Builder's Association as part of her professional networking. Somewhat unexpectedly, the organization decided to move its headquarters to a new facility, which needed to be built quickly. Because the job was small (under 2000 square feet) and one-of-a-kind, there was not great interest in the project from the other association members because they were primarily residential builders. Chung was able to bid on, and then secure the contract. In order to bid, she needed to estimate the cost of installing drywall, a task in which she had no practical experience. She was able to convince a small local subcontractor to show her how to develop an accurate estimate. Ultimately, that favor done by the subcontractor led to a long term relationship that proved beneficial to both parties. As Chung worked more jobs, she always made sure that he had the opportunity to bid on the drywall. From her perspective, it meant that she could always count on getting a fair price and quality work on any project she undertook.

Over the next 20 years, Chung continued to undertake a wide variety of projects. She also spent considerable effort on personal and professional development. In 1997, she became licensed as a professional engineer in Florida. More recently, she earned the LEED AP designation, making her more attractive to the increasing number of clients interested in energy efficient buildings. She also took advantage of her natural knack for languages and could now converse effectively in six: English, Taiwanese (her parents' native tongue), Spanish (critical for anyone doing construction in Florida), French, Japanese, and Mandarin. At the time of the case, she was well on her way to learning a seventhKorean - which she suspected might open up many future opportunities; in 2011 Rotary International selected her as a Group Study Exchange leader to host a group of young professionals from Florida's gulf coast to South Korea, one of the fastest growing economies in Asia. 


\section{Current Period}

Throughout her two decades in the business, real estate construction had gone through a number of boom and bust cycles - as had been typical for centuries. The new millennium, however, had been like nothing anyone had ever seen. During the five year period from 2001-2006, real estate_particularly residential real estate - had experienced a surge in demand and prices. Then, abruptly in 2007, demand and prices began to plummet. The extraordinary magnitude of these fluctuations is illustrated in Exhibit 2, showing housing starts in the U.S. and South. By 2010, construction activity was less than 1/3 of its 2006 peak.

For a small business like Ivy Ventures, maintaining revenue in this environment required extreme adaptability. Fortunately, Chung had been able to identify opportunities outside of her traditional business sphere. The most successful of these came in 2009, when she had bid for consulting work on the renovation of Ed Smith Stadium, which was to become the spring training facility for the Baltimore Orioles in 2010. Prior to that time, the Sarasota stadium had played host to the Cincinnati Reds, who had moved their spring training to Arizona in 2008. In order to get the Orioles, who signed a 30-year contract, Sarasota County had to contribute to a $\$ 31.2$ million renovation of Ed Smith Stadium for Major League Baseball and the Buck O'Neil Baseball Complex at Twin Lakes for Orioles' Minor League training. Throughout these two renovations, Chung served as a consultant for the County and also as a liaison among the architects, contractors, and subcontractors. She even specialized in wage compliance (where her Spanish proved valuable when interviewing laborers or roofers to meet the Davis-Bacon Wage Act) as well as LEED administration (as she monitored the LEED efforts of getting Ed Smith Stadium to become LEED Gold-certified, which would make it the first LEED Gold spring training facility in the U.S.). The construction was largely complete by Opening Day-March 1, 2011, although follow-up activities, also referred to as the "punch list", continued for some time after that.

Chung had also engaged other consulting projects during the period. Not afraid to leverage her strong technical skills to venture outside of her area of expertise, she had moderated a project for a major foreign automobile manufacturer seeking to determine what - if any - modifications would be required to a radical new automobile instrumentation design to be released in 2013. Her job had been to conduct consumer trials in the U.S. on a simulator and observe how the new layout impacted the American driver's ability to react to changing conditions.

\section{Networking Activities}

In addition to her adaptability and experience, Chung felt that her ability to develop and nurture professional relationships had been critical to her company's survival over the last four difficult years. Chung networked because she enjoyed it and because she felt the obligation to give back to the community. Nonetheless, she had to admit that the contacts that she had developed often led to business opportunities. Some of her service and professional outside activities included:

- Rotary Club: With its motto "service above self," Rotary boasts 34,000 clubs worldwide dedicated to service activities. Chung nearly always attended the weekly luncheon or make ups in New York City, Park City (during the 2002 Winter Olympics), Hawaii, and Hong Kong, arranged for a homestay in Salamanca, Spain, and participated in events, such as Rotary International's Group Study Exchange - her upcoming trip to lead young professionals to South Korea.

- Ringling Museum: She was a co-founder of the Ringling Fan Club, which was instrumental in developing membership (for young professionals and new residents) and patronage to this state art museum located in Sarasota. 
- Alumni Association: She served as president of the Columbia University Club of Sarasota. She not only invited distinguished speakers (including USF Professor Susan MacManus to speak on the 2010 Presidential Elections, Columbia Dean of Social Work Jeanette Takamura (former Assistant Secretary for Aging at the U.S. Department of Health and Human Services), Gwen MacKenzie (CEO of Sarasota Memorial Health Care) and Columbia Law Professor Nate Persily (to address Elections 2012 and Congressional re-districting), but also spearheaded alumni events at the ballpark (Yankees vs. Orioles), Circus Sarasota and receptions for worldwide networking. As a consequence of these activities, Chung often found she was featured by the local pressboth in the social and business sections. This type of publicity could sometimes be a source of new business; it always served as a reminder to past clients of her services.

As a consequence of these activities, the local press often featured Chung - in the social, community, and business sections. This type of publicity became valuable as not only developing public relations or reminding past clients of her community involvement, but also becoming a source for new business.

In addition to these formal organizations and effective press releases, Chung personalized her customer service. For example, many of her clients were bankers. When she completed reports, such as those required for construction progress payments, she would always hand-deliver them, rather than using a courier or the mail. By doing so, she tacitly had continued "face time" with her clients. She felt that being local, reliable, convenient, and available were among her greatest competitive strengths.

\section{Technology}

Based on her past experience, Chung felt that word-of-mouth and networking were likely to be far more productive in generating business leads than technology. This attitude did not reflect any underlying fear of technology. In her day-to-day work life, she used technology continuously. Her PC laptop-with its fuchsia keyboard and color-coordinated mouse - was critical to almost every aspect of her business and was her nearly constant companion. She had an iPhone with many apps, although she admitted that she was very conservative in what apps to try, relying almost exclusively on the advice of friends and colleagues. She used email daily, employed web-based search engines routinely, and even had an account on Linked-In, the business counterpart to the Facebook social networking phenomenon, although it had yet to prove useful.

Over the coming year, Chung had committed to embark on a new technology-based activity. Over the past three years, she had developed unique insights into the design and construction of sports venues. She had agreed to share these insights on a new blog that would be hosted on Yahoo! Sports. She expected to post a new article every month or so, depending upon public reaction. Such a blog, she hoped, would not only prove informative to its readers but could also act as a source of business leads on a national basis.

In spite of all the technology that she did use, there were a great many applications that she ignored. She did not maintain a Facebook account. She was not on Twitter. She did not have a web site. All of these would require her time to set up and maintain. No one had yet been able to convince her that she would be paid back through increased business. She had no interest in developing a presence just to massage her own ego. There were plenty of other ways that she could spend her time that seemed more likely to prove profitable.

\section{Possible Web Site}

Chung summed up her situation as follows:

"It is somewhat ironic that I am an engineer but do not have my own web site." 
During the summer of 2011, in fact, she had mentored a Dartmouth engineering student who suggested a website and began developing one for her Ivy Ventures. Although they had made some progress, when the summer ended the student had gone back to college and the project had more-or-less been abandoned.

Was it time to reconsider? Given the long-lived real estate slump, any opportunity with genuine potential for generating business was worth exploring. Nevertheless, she remained unconvinced that a web site would provide significant benefits for her. It might even be an obstacle. Not having a web site, potential clients needed to speak with her face-to-face or on the phone. She felt that she was particularly strong communicating in this way. What if they found her web site and chose not to investigate further?

On the other hand, she had no way of knowing if she had lost client leads in the past because they could not find a web site that described her business. It is hard to tell what is on the mind of someone who does not call. Was she losing business and not even knowing about it?

Of one thing she was sure. Any web site that was attractive to her would certainly have a number of characteristics:

- It would affirm her personal style and not undermine it. Far more people knew her by name than by her company, Ivy Ventures. Part of that she attributed to her carefully cultivated style. A web site would need to support that style. The last thing she wanted was some sort of generic presence on the web that shouted out, "There is nothing unique about this person!"

- It would complement her current networking activities and public presence. Networking had been a key factor in the success of her business. Any web site she developed should work with those activities. Furthermore, now that she was about to launch a blog and had established an identity on LinkedIn - although she admitted that she had never bothered to learn how to use it - she did not want to be duplicating the same information on multiple sites. Doing so, she recognized, would not only mean unnecessary work but also meant that some elements of her web presence could easily end up out-of-date.

- It would be readily adaptable to her continuously changing business activities. As noted earlier, much of her success was the result of her willingness to seek out, and even invent, new business opportunities. She definitely did not want a site that would pigeon-hole her to a specific business and would require major changes each time she did something different.

- It would be able to prove its value. To Chung, a web site's value necessarily derived from the business it generated, not from vanity. It would be desirable to have some means of determining that value. As an example, she pointed out that for years she had signs installed with her corporate logo (redesigned in 2011), company name, phone number, and even her personal name on work sites where she was involved. She had yet to have anyone call based on those signs (at least as far as she knew). Chung stated: "In these tough economic times, the signs serve as a visual aid to let people know that Ivy Ventures is still in business."

- It would require maintenance at a level consistent with its proven value. Chung recognized that a web site was not forever, and would - from time-to-time - need to be freshened. She was certainly willing to do such updating provided the value was there. She had better things to do with her time than maintain a web site that was not producing leads.

With her sports venue blog about to launch, Chung expected a lot more people to start searching for her on the web. It seemed like a good time to re-open the entire web site decision. In fact, perhaps what was needed was a comprehensive online strategy of which the web site would just be a part. 


\section{Exhibit 1: General Contractor Definition}

Selection from the 2011 Florida Statutes, Chapter 489: CONTRACTING.

489.105 Definitions. - As used in this part:

(3) "Contractor" means the person who is qualified for, and is only responsible for, the project contracted for and means, except as exempted in this part, the person who, for compensation, undertakes to, submits a bid to, or does himself or herself or by others construct, repair, alter, remodel, add to, demolish, subtract from, or improve any building or structure, including related improvements to real estate, for others or for resale to others; and whose job scope is substantially similar to the job scope described in one of the subsequent paragraphs of this subsection. For the purposes of regulation under this part, "demolish" applies only to demolition of steel tanks over 50 feet in height; towers over 50 feet in height; other structures over 50 feet in height, other than buildings or residences over three stories tall; and buildings or residences over three stories tall. Contractors are subdivided into two divisions, Division I, consisting of those contractors defined in paragraphs (a)-(c), and Division II, consisting of those contractors defined in paragraphs (d)-(r):

(a) "General contractor" means a contractor whose services are unlimited as to the type of work which he or she may do, who may contract for any activity requiring licensure under this part, and who may perform any work requiring licensure under this part, except as otherwise expressly provided in s. 489.113.

(b) "Building contractor" means a contractor whose services are limited to construction of commercial buildings and single-dwelling or multiple-dwelling residential buildings, which do not exceed three stories in height, and accessory use structures in connection therewith or a contractor whose services are limited to remodeling, repair, or improvement of any size building if the services do not affect the structural members of the building.

(c) "Residential contractor" means a contractor whose services are limited to construction, remodeling, repair, or improvement of one-family, two-family, or three-family residences not exceeding two habitable stories above no more than one uninhabitable story and accessory use structures in connection therewith. 


\section{Exhibit 2: U.S. Housing Starts}

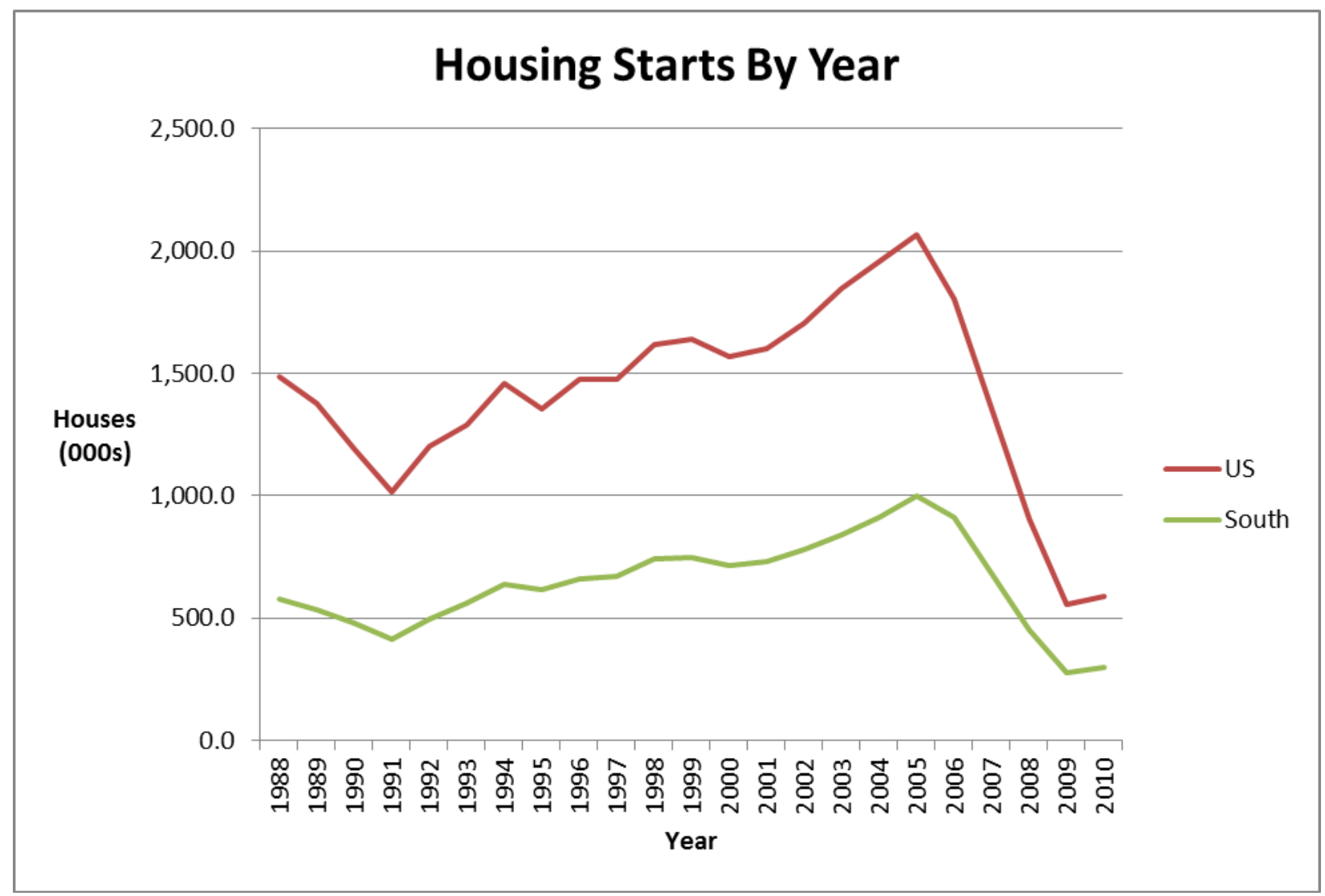

Source: U.S. Census (http://www.census.gov/construction/nrc/historical_data/) 